\title{
Longshore distribution of Donax serra in two log-spiral bays in the eastern Cape, South Africa
}

\author{
Theodore E. Donn, Jr.
}

Department of Zoology, Institute for Coastal Research, University of Port Elizabeth, Box 1600, Port Elizabeth 6000, South Africa

\begin{abstract}
The distribution and abundance of the white mussel Donax serra Röding was investigated in 2 log-spiral bays in the eastern Cape, South Africa. The distribution was found to be similar in both bays, abundance increasing to points about 10 and $20 \mathrm{~km}$ east of the major rivers, Gamtoos and Sundays, respectively, and declining beyond. The abundance of recruits, 10 to $16 \mathrm{~mm}$ in length, peaked closer to the river mouths than the total population. An hypothesis combining longshore drift of immature individuals and larval settlement near river mouths is proposed to explain the differences in longshore population structure.
\end{abstract}

\section{INTRODUCTION}

Studies on the distribution of organisms within the intertidal and shallow subtidal zones of sandy shores have been primarily concerned with zonation aiong the intertidal, or vertical gradient (Ansell et al. 1972, Croker et al. 1975, Shelton \& Robertson 1981, Bally 1983). Some researchers (McIntyre \& Eleftheriou 1968, Corey 1970, Fincham 1971) have considered the alongshore or lateral variation in the distribution of organisms, while few studies (Loesch 1957, Dillery \& Knapp 1970, Dauer \& Simon 1975, Mouëza \& Chessel 1976) have attempted to describe these patterns.

The sand-burrowing bivalve Donax serra is the largest member of the genus and the dominant organism on many sandy beaches in southern Africa (Ansell 1983). McLachlan \& Hanekom (1979), working in St. Francis and Algoa Bays, South Africa, reported that $D$. serra was more abundant on more exposed beaches, and suggested that particulate matter from river mouths and phytoplankton blooms may also have an effect on population sizes. Casual observations along the Sundays River beach indicated that $D$. serra population sizes increased eastwards.

As the Donax serra population $2 \mathrm{~km}$ east of the Sundays River mouth was being studied for growth and production (Donn \& McLachlan unpubl.), it was decided to survey the population along the entire beach to extend the results from the study site to the whole population. This sampling was further extended to cover most of the sandy coastline in Algoa Bay and the adjacent St. Francis Bay to confirm the observed patterns. In this report the longshore distributional patterns of $D$. serra are described and an hypothesis explaining them is proposed.

\section{METHODS}

The sandy beaches in the eastern Cape, South Africa, from the Kabeljous River to Maitland River in St. Francis Bay, a distance of $35 \mathrm{~km}$, and from the Swartkops River to Woody Cape in Algoa Bay, covering $60 \mathrm{~km}$ (Fig. 1), were sampled during spring low tides at $5 \mathrm{~km}$ intervals between January and March 1985. At each site, 2 transect lines $50 \mathrm{~m}$ apart were sampled. Along each line, $0.25 \mathrm{~m}^{2}$ quadrats were taken at $3 \mathrm{~m}$ intervals to a depth of approximately $30 \mathrm{~cm}$ in the sand, throughout the Donax serra band. Sand removed from the quadrats was sieved through a $4 \mathrm{~mm}$ mesh sieve which effectively retains $D$. serra greater than $9 \mathrm{~mm}$ in length. The antero-posterior lengths of all $D$. serra collected were measured in the field to the nearest $1 \mathrm{~mm}$ with vernier calipers and the individuals immediately returned to the sampled quadrat and covered with sand. Beach slopes were taken along each transect line. At each sampling location a sand sample was taken using a coring device and analysed for mean grain size and sorting in an Emery settling tube; additional sand samples were also taken at regular intervals between the sites.

A series of duplicated $10 \mathrm{~m}$ long tows for Donax serra 


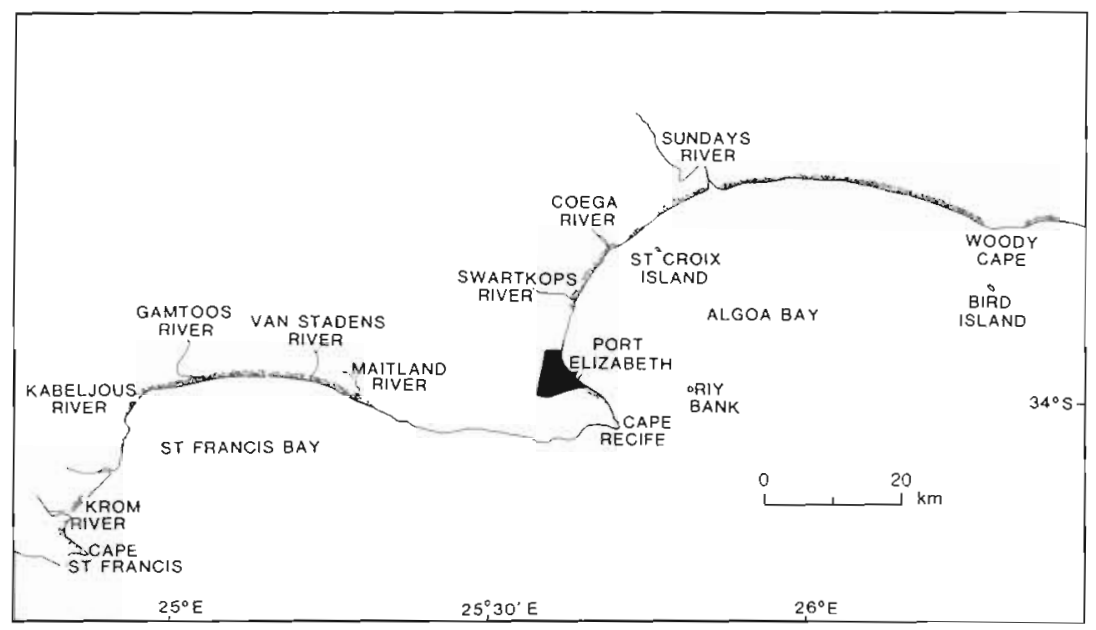

Fig. 1. Map of study areas in St. Francis and Algoa Bays, South Africa. Sandy beaches are indicated by shading. The mouths of the Kabeljous, Van Stadens, Maitland, and Coega Rivers are closed by sandbanks. The mouths of the Gamtoos, Swartkops, and Sundays Rivers remain open

of 2 to $5 \mathrm{~mm}$ length were taken during June 1985 on the Sundays River beach just below spring low water. A $0.5 \mathrm{~m}$ wide sled sampler of $1 \mathrm{~mm}$ mesh was used to sample the top $1 \mathrm{~cm}$ of sand (Wooldridge 1981). These data provide a semi-quantitative estimate of the density of the smaller individuals.

\section{RESULTS}

The abundance (number per metre) of Donax serra in Algoa and St. Francis Bays are displayed in Fig. 2. Both bays have low population sizes to the west of the major river mouths (Sundays River and Gamtoos River). Eastward of the river mouths population sizes increased to a maximum at 20 and $10 \mathrm{~km}$, respectively, and declined thereafter. Average abundances and biomasses for the regions east of the river mouths were 1508 ind $\mathrm{m}^{-1}$ and $1515 \mathrm{~g} \mathrm{~m}^{-1}$ for Algoa Bay, and 4129 ind $\mathrm{m}^{-1}$ and $3654 \mathrm{~g} \mathrm{~m}^{-1}$ for St. Francis Bay. The population size structure also changed along the beaches. In Fig. 3, the length-frequency histograms for each sampling site east of the Sundays River and east of the Gamtoos River are presented. Due to the smail numbers of individuals collected westwards of the rivers, data from these sites are not presented. While the total size range of individuals in the population was similar throughout the beach, the relative proportions of recruits ( 9 to $16 \mathrm{~mm}$, less than 6 mo after recruitment) and sexually mature adults ( $\geq 45 \mathrm{~mm}$ ) changed, recruits making up a greater proportion of the populations near the river mouths (Fig. $4 \mathrm{a}, \mathrm{b}$ ). The populations to the west of the river mouths were dominated ( 40 to $80 \%$ ) by recruits, while to the east the proportion of recruits declined from approximately $70 \%$ near the mouths to $5 \%$ at the furthest points. The absolute numbers of recruits in both bays was maximal $5 \mathrm{~km}$ east of the river mouths (Fig. 5a, b), implying nonuniform recruitment along the beach. Beach slope and mean grain size showed no trend along the beaches sampled. A comparison of the abundances of $D$. serra on each of the paired lines indicated that the bivalves were more abundant on the line with the flatter slope (Chi-square, $p<0.001$ ).
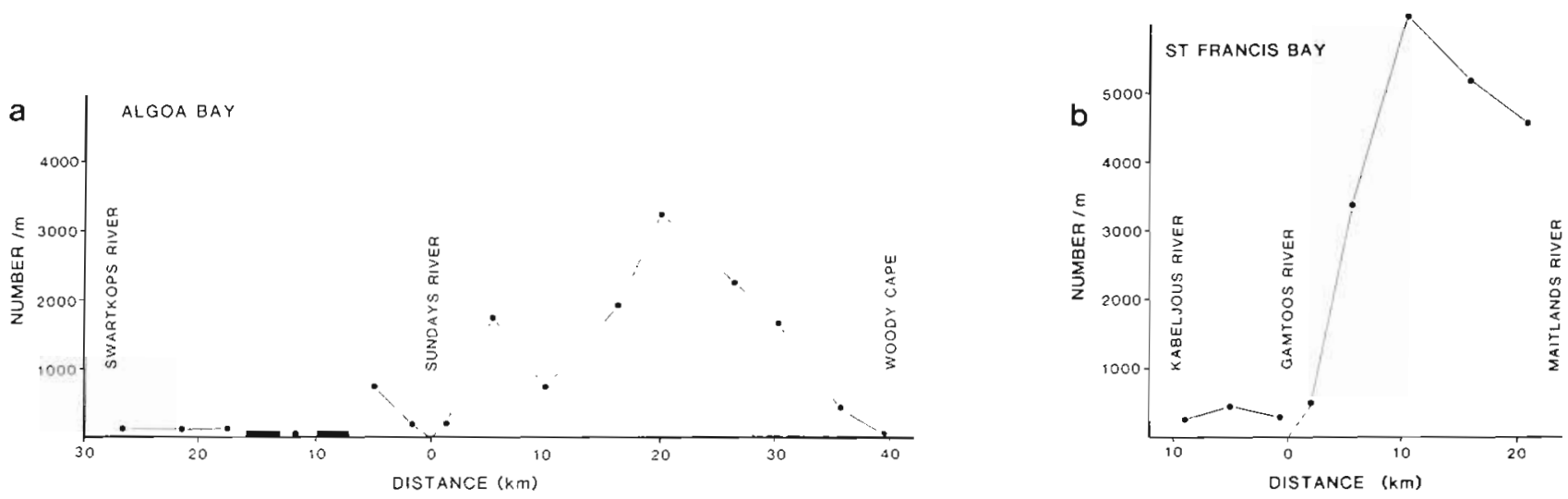

Fig. 2. Donax serra. Total population sizes at each sampling location in (a) Algoa Bay and (b) St. Francis Bay. Bars on the $x$-axes indicate stretches of rock 
SUNDAYS RIVER
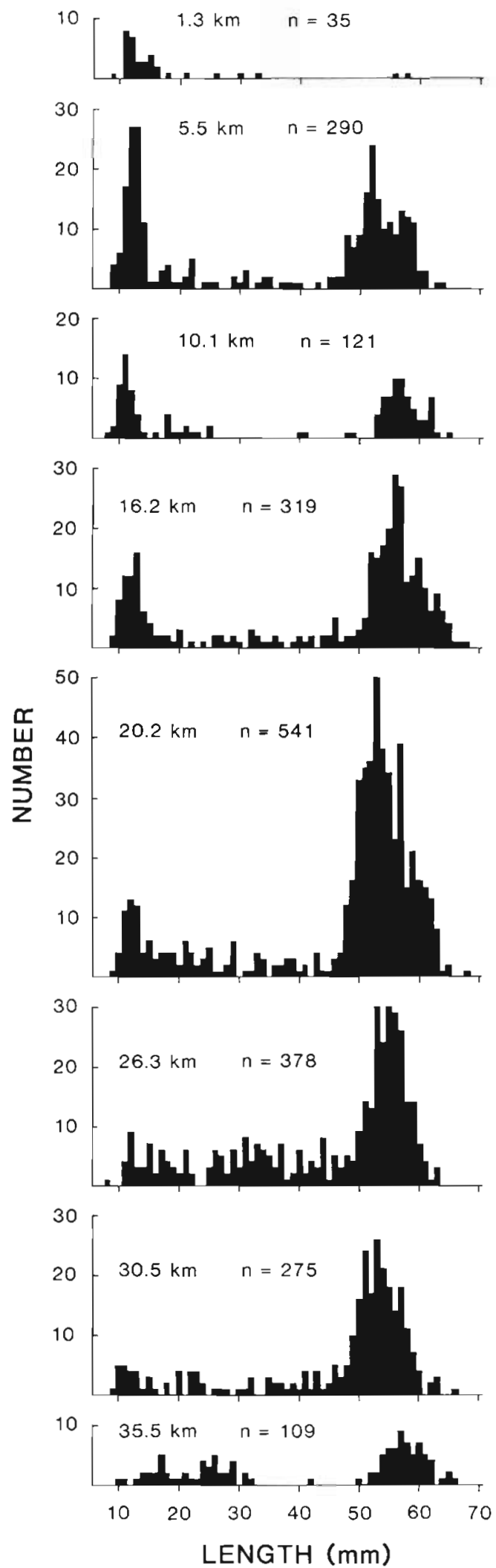

GAMTOOS RIVER
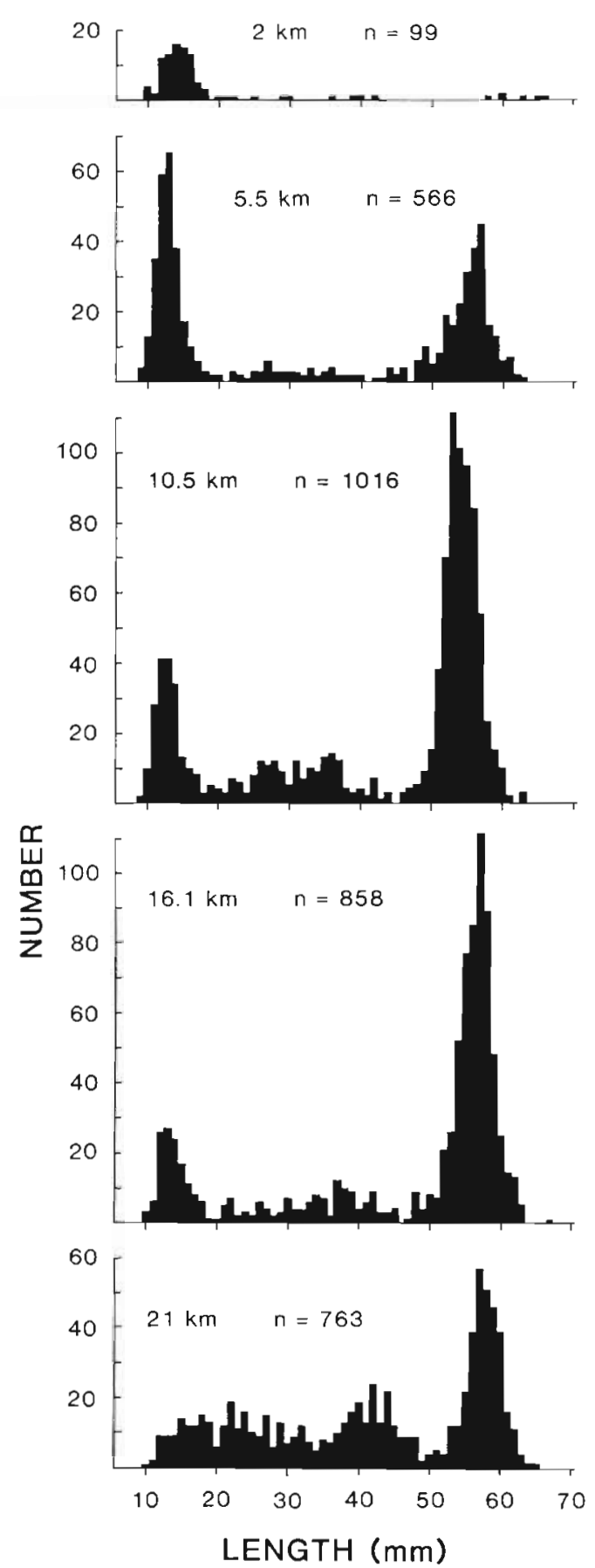

Fig. 3. Donax serra. Length-frequency histograms for sampling sites east of Sundays River and Gamtoos River. Distances are given as kilometres east of the river mouths 

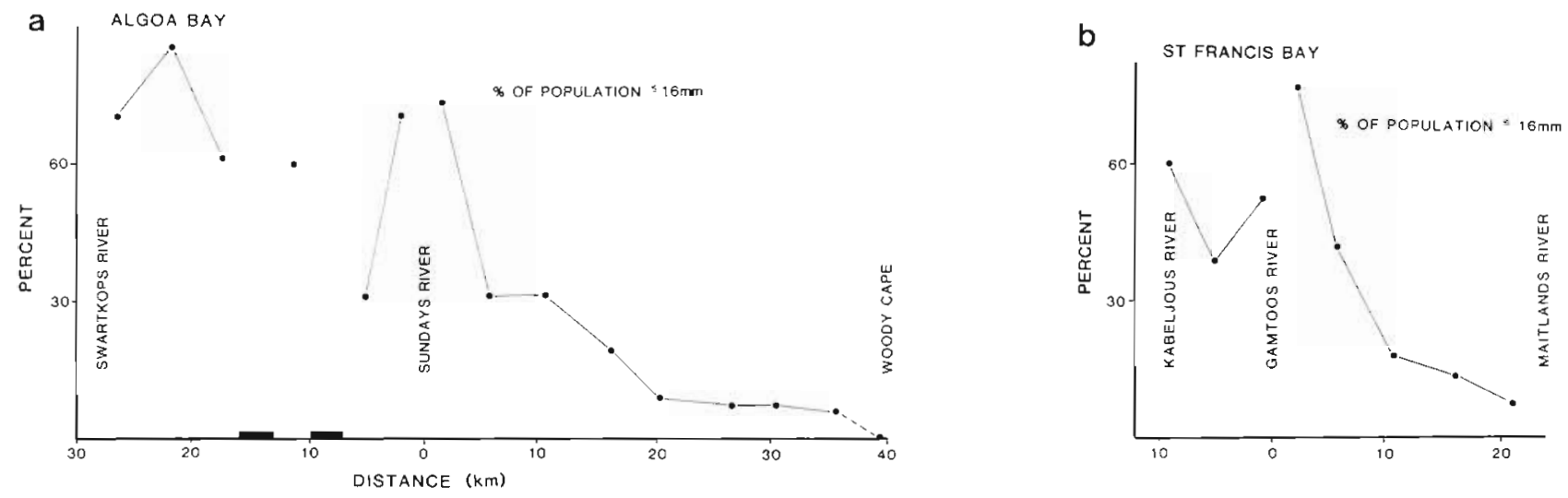

Fig. 4. Donax serra. Percent of total population composed of recruits $16 \mathrm{~mm}$ or less in length in (a) Algoa Bay and (b) St. Francis Bay
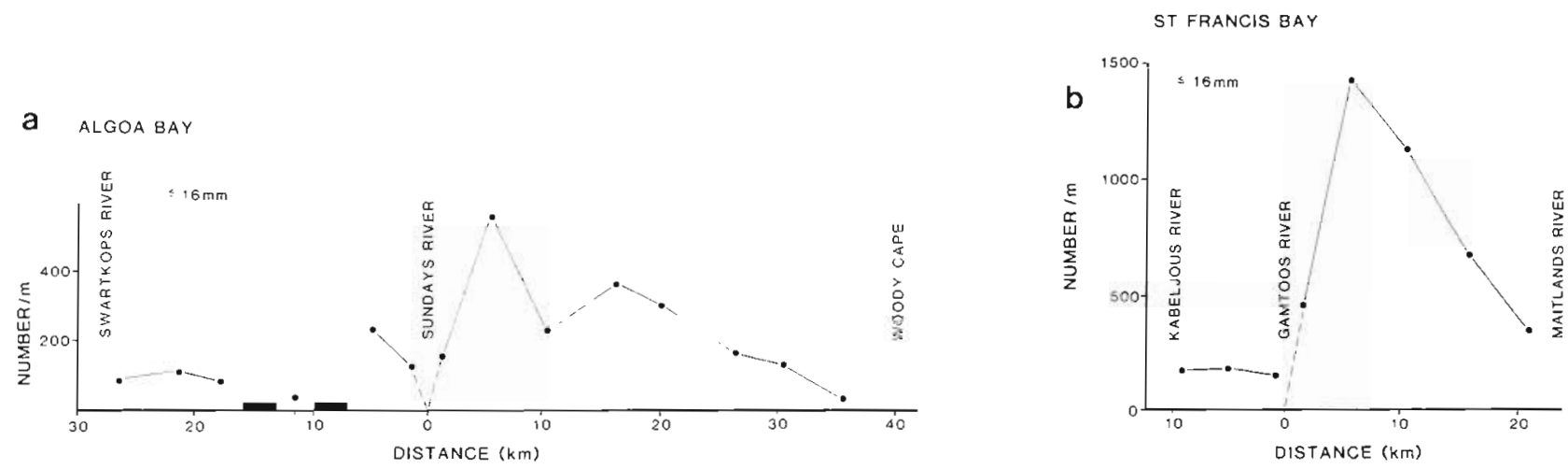

Fig. 5. Donax serra. Abundances of recruits $16 \mathrm{~mm}$ or less in length in (a) Algoa Bay and (b) St. Francis Bay

The June sled survey was designed to test the hypothesis that the smallest individuals, 2 to $5 \mathrm{~mm}$, would be found close to the Sundays River mouth. Fig. 6 displays the number of individuals collected per $10 \mathrm{~m}$ sled tow, or a total sampling area of $5 \mathrm{~m}^{2}$, just below the low-tide line. Since sampling did not cover the entire spat distribution, these data provide only a semi-quantitative estimate of the population size. The data support the original hypothesis concerning distribution. Densities are maximum close to the Sundays River mouth and decline rapidly to about the $10 \mathrm{~km}$ mark. The data also show a minor peak in density at the $20 \mathrm{~km}$ mark. This peak is not, however, observed in the abundance of recruits (Fig. 5a).

\section{DISCUSSION}

Other studies (McIntyre \& Eleftheriou 1968, Corey 1970, Fincham 1971, Dauer \& Simon 1975) have shown differential distribution of sandy beach organisms in the alongshore direction. Factors considered important in determining species composition and abundance were exposure or wave action (McIntyre \& Eleftheriou

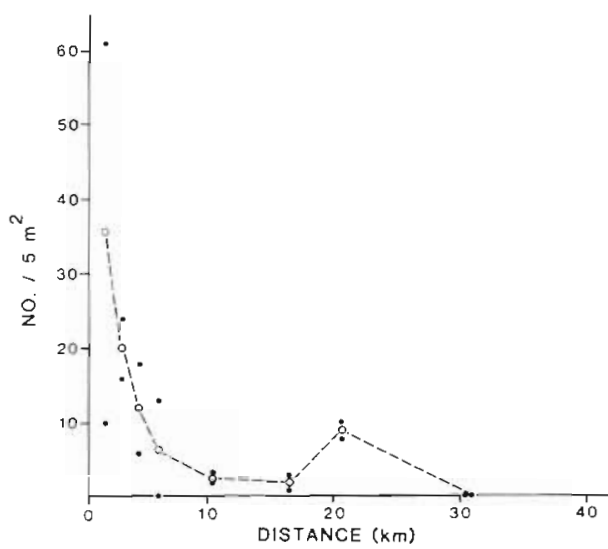

Fig. 6. Donax serra. Number of 2 to $5 \mathrm{~mm}$ individuals per $5 \mathrm{~m}^{2}$ tow along the beach east of the Sundays River mouth. (•) Observed densities; (---o) means

1968), grain size (Corey 1970, Fincham 1971), and immigration rates (Dauer \& Simon 1975). Sastre (1984) examined Donax denticulatus populations on 5 Puerto Rican beaches in terms of several environmental variables. He found that population abundance and maximum size of individuals was greatest on those beaches with the highest levels of particulate organic carbon, 
and concluded that food availability was a major parameter affecting the populations.

All members of the genus Donax are filter feeders (Ansell 1983). In the eastern Cape, D. serra feeds extensively on the surf zone diatom Anaulus birostratus which composes $>95 \%$ of the phytoplankton standing stock and can reach densities up to $6 \times 10^{6}$ cells $\mathrm{ml}^{-1}$ in a bloom (Campbell \& Bate in press). Patches of $A$. birostratus are more frequent and of a larger size and intensity 20 to $25 \mathrm{~km}$ east of the Sundays River mouth than at the mouth or at Woody Cape (E. Campbell \& G. C. Bate pers. comm.). Phytoplankton blooms occur very infrequently between the Swartkops River and Sundays River. A more abundant food source may allow for increased survivorship and hence a larger population size.

However, it was not only population abundances that differed along the shore, but also the population structure (Fig. $3 \& 4$ ). Patterns of food availability cannot explain the changing pattern in population structure. This pattern was similar in both bays, which suggests a physical rather than a biological explanation. Any proposed mechanism to explain these data must be able to account for the observed differential distribution of recruits and adults, and provide a means of transforming the recruit distribution into the adult distribution over time.

Loesch (1957) and Mouëza \& Chessel (1976) examined the longshore distribution of Donax spp. in Texas and Algiers, respectively. Loesch (1957) found a differential size distribution of $D$. variabilis with many small individuals in the southern samples and fewer large ones at the northern stations along the beach. This distribution is similar to, but more dramatic than, the distribution patterns in the present case. Loesch (1957), however, does not offer an explanation for this distribution. Mouëza \& Chessel (1976) examined the $D$. trunculus population along a beach $1200 \mathrm{~m}$ long and bounded by 2 headlands. They also found differential population structure along the beach. Their data indicate a uniform settlement of juveniles followed by differential mortality due to a gradient of food availability. They invoked a closed circulation pattern with longshore currents moving away from the adults to explain the settlement pattern. In $D$. serra, settlement appears to be strongly skewed towards the river mouths. Dillery \& Knapp (1970) tagged and followed individual Emerita analoga and found that the crabs moved along the beach in the same direction as the longshore current.

Many species of Donax have been shown to migrate with tides, maintaining themselves within the swash zone (Loesch 1957, Turner \& Belding 1957, Wade 1967 , Tiffany 1972, McLachlan et al. 1979, Leber 1982, Ansell 1983). Wade (1967) stated that Donax denticulatus can control the timing of its emergence from the sediments and whether it moves upshore or downshore. D. serra has been shown to exhibit a semilunar (spring-neap) pattern of migration on the beach (McLachlan et al. 1979, Prosch \& McLachlan 1984, Donn et al. in press). During these migrations, $D$. serra emerge from the sediments and are moved up or down the beach by the swash before reburrowing at new levels (Trueman 1971, Ansell \& Trueman 1973). These observations indicate that $D$. serra has the ability to control its emergence from the sediments and whether it moves upshore or downshore and perhaps the amount of this movement. When the bivalves are rolling in the swash, they can be moved laterally due to wave action and longshore currents.

Algoa and St. Francis Bays are of the type termed log-spiral. The dominant southwesterly winds and oceanic swells approaching the eastern Cape coast are responsible for the shape of these bays (Bremner 1983). As a result of these factors, one would expect the predominant longshore current to be in a clockwise or easterly direction within these bays. Data from Krumbein (1944) on Half Moon Bay on the California coast, and Baker \& Edwards (1955) on Portland Bay in Victoria, Australia, show similar patterns of circulation. Researchers from the National Research Institute for Oceanology, Cape Town, have measured the longshore currents near the mouth of the Sundays River and have determined that approximately $85 \%$ of the time the longshore currents flow in an easterly direction $(\mathrm{H}$. Swart pers. comm.).

Rough estimates of the necessary drift for recruit distribution to match adult distribution in the course of $2 \mathrm{yr}$ indicate that an average movement rate of 5 to $10 \mathrm{~m} \mathrm{~d}^{-1}$ is required. Baker \& Edwards (1955) have shown that marker minerals dumped near a river mouth (analogous in location to Sundays River) in a log-spiral bay in Australia can disperse up to $6 \mathrm{~m} \mathrm{~d}^{-1}$ eastwards, while some also disperses $4 \mathrm{~m} \mathrm{~d}^{-1}$ westwards. Talbot \& Bate (unpubl.) have shown that, at high tide, nearshore currents along the Sundays River beach are primarily in the alongshore direction, averaging $0.42 \mathrm{~m} \mathrm{~s}^{-1}$ alongshore over 5 separate sampling accasions. At this rate a Donax serra will have to remain in the swash for approximately $15 \mathrm{~s}$ per $\mathrm{d}$ in order to move the necessary distance. During a single occasion with a light southwesterly wind and 3 to $4 \mathrm{~m}$ waves, an average longshore current of $0.33 \mathrm{~m} \mathrm{~s}^{-1}$ was measured along a $150 \mathrm{~m}$ long stretch of beach (Donn \& Talbot unpubl. data). At this time large numbers of $D$. serra were observed to be actively moving in the swash. At the observed current speeds an individual bivalve could cover the necessary distance by being present in the swash for as little as $20 \mathrm{~s}$. Donn \& McLachlan (unpubl.) have shown that the density of 
$D$. serra increases with length, ranging from approximately $1.3 \mathrm{~g} \mathrm{~cm}^{-3}$ at $15 \mathrm{~mm}$ to $1.5 \mathrm{~g} \mathrm{~cm}^{-3}$ at $55 \mathrm{~mm}$ Therefore, smaller individuals may be moved more readily than larger ones.

The differential pattern of settlement of Donax serra close to the Sundays and Gamtoos River mouths suggests some form of larval selection for these sites. The cues for settlement are as yet unknown. Ansell (1983) states that the average larval lifespan for members of

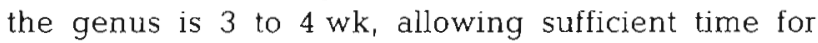
dispersal of the larvae. The offshore current patterns in St. Francis and Algoa Bays are unknown at present, and therefore the analysis of larval movements must be deferred until the current patterns are resolved.

In summary, the distribution patterns of Donax serra in 2 adjacent log-spiral bays have been found to be similar; young individuals immediately east of the river mouths, and more and larger individuals occurring further eastwards. To explain these observations the following hypothesis is proposed. The larvae initially settle near to the river mouths in response to some as yet unknown cue. As the individuals grow and while undertaking intertidal migrations they are carried in a clockwise direction around the bays by the predominant longshore currents at an average daily rate of 5 to $10 \mathrm{~m}$. This results in the observed distribution patterns.

Acknowledgements. I acknowledge the support of a C.S.I.R. Postdoctoral Bursary during the course of this study. Support for the research was obtained from a South African Committee on Research grant to the University of Port Elizabeth Surf Zone Program under the direction of Prof. A. McLachlan. P. du Toit, D. van der Merwe, P. Jonker, W. Hlenberger, J. A. Erasmus, B. Talbot, Dr D. A. Lord and Prof. A. McLachlan provided field assistance. Drs. Lord and E. Schuman provided useful discussions of physical parameters. M. Hawkins and P. J. McLachlan assisted with the preparation of figures.

\section{LITERATURE CITED}

Ansell, A. D. (1983). The biology of the genus Donax. In: McLachlan, A., Erasmus, T (ed.) Sandy beaches as ecosystems. Junk Publ., The Hague, p. 607-636

Ansell, A. D., Trueman, E. R. (1973). The energy cost of migration of the bivalve Donax on tropical sandy beaches. Mar. Behav. Physiol. 2: 21-32

Ansell, A. D., Navayanan, B., Trevallion, V. N., Trevallion, A (1972). The ecology of two sandy beaches in southwest India. I. Seasonal changes in physical and chemical factors, and in the macrofauna. Mar. Biol. 17: 38-62

Baker, G., Edwards, A. B. (1955). Sand drift at Portland, Victoria. II. Movement of marker minerals. C.S.I.R.O. Mineragraphic Investigations Rep. 635, p. 1-17

Bally, R. (1983). Intertidal zonation on sandy beaches of the west coast of South Africa. Cah. Biol. mar. 24: 85-103

Bremner, J. M. (1983). Properties of logarithmic spiral beaches with particular reference to Algoa Bay. In: McLachlan, A., Erasmus, T. (ed.) Sandy beaches as ecosystems. Junk Publ., The Hague, p. 97-114
Campbell, E. E., Bate, G. C. (in press). Factors influencing the magnitude of phytoplankton production in a high energy surf zone. Estuar. coast. Shelf. Sci.

Corey, S. (1970). The quantitative distribution of three Cumacea (Crustacea, Peracarida) in Kames Bay, Scotland. Can. J. Zool. 48: 925-930

Croker, R. A., Hager, R. P., Scott, K. J. (1975). Macroinfauna of northern New England marine sand. II. Amphipod dominated intertidal communities. Can. J. Zool. 53: 42-51

Dauer, D. M., Simon, J. L. (1975). Lateral or along-shore distribution of the polychaetous annelids of an intertidal sandy habitat. Mar. Biol. 31: 363-370

Dillery, D. G., Knapp, L. V. (1970). Longshore movements of the sand crab, Emerita analoga (Decapoda, Hippidae). Crustaceana 18: 233-260

Donn, T. E., Jr., Clarke, D. J., McLachlan, A., du Toit, P. (in press). Distribution and abundance of Donax serra Röding (Bivalvia: Donacidae) as related to beach morphology. I. Semilunar migrations. J. exp. mar. Biol. Ecol.

Fincham, A. A. (1971). Ecology and population studies of some intertidal and sublittoral sand-dwelling amphipods. J. mar. biol. Ass. U.K. 51: 471-468

Krumbein, W. C. (1944). Shore processes and beach characteristics. Tech. Memorandum 3, U.S. Army Corps of Engineers, p. 1-35

Leber, K. M. (1982). Bivalves (Tellinacea: Donacidae) on a North Carolina beach: contrasting population size structures and tidal migrations. Mar. Ecol. Prog. Ser. 7: 297-301

Loesch, H. C. (1957). Studies on the ecology of two species of Donax on Mustang Island, Texas. Univ. of Texas Inst. Mar. Sci. Publ. 4 (2) : 201-227

McIntyre, A. D., Eleftheriou, A. (1968). The bottom fauna of a flatfish nursery ground. J. mar. biol. Ass. U.K. 48: 113-142

McLachlan, A., Hanekom, N. (1979), Aspects of the biology, ecology, and seasonal fluctuations in biochemical composition of Donax serra in the East Cape. S. Afr. J. Zool. 14: 183-193

McLachlan, A., Wooldridge, T., van der Horst, G. (1979). Tidal movements of the macrofauna on an exposed sandy beach in South Africa. J. Zool. 187: 433-442

Mouëza, M., Chessel, D. (1976). Contribution a l'étude de biologie de Donax trunculus L. (Mollusque: Lamellibranche) dans l'Algerios: analyse statistique de la dispersion de long d'une plage en Baie de Bou Ismail. J. exp. mar. Biol. Ecol. 21: 211-221

Prosch, R. M., McLachlan, A. (1984). The regeneration of surfzone nutrients by the sand mussel, Donax serra Röding. J. exp. mar. Biol. Ecol. 80: 221-233

Sastre, M. P. (1984). Relationship between environmental factors and Donax denticulatus populations in Puerto Rico. Estuar, coast. Shelf Sci. 19: 217-230

Shelton, C. R., Robertson, P. B. (1981). Community structure of intertidal macrofauna on two surf-exposed Texas sandy beaches. Bull. mar. Sci. 31: 833-842

Tiffany, W J., III. (1972). The tidal migration of Donax variabilis Say (Mollusca: Bivalvia). Veliger 14: 82-85

Trueman, E. R. (1971). The control of burrowing and the migratory behavior of Donax denticulatus (Bivalvia: Tellinacea). J. Zool. 165: 453-469

Tumer, H. J., Jr., Belding, D. L. (1957). The tidal migrations of Donax variabilis Say. Limnol. Oceanogr. 2: 120-124

Wade, B. A. (1967). Studies on the biology of the West Indian beach clam Donax denticulatus Linné. 1. Ecology. Bull. mar. Sci. 17: 149-174

Wooldridge, T H. (1981). Zonation and distribution of the beach mysid, Gastrosaccus psammodytes (Crustacea: Mysidacea). J. Zool. 193: 183-189 